\title{
IMPLANTATION IN LACTATING RATS TREATED WITH INSULIN*
}

\author{
NIVA SHAPIRA, J. KALI AND S. AMIR \\ Division of Cattle Nutrition and Physiology, The Volcani Center, \\ Agricultural Research Organization, Rehovot, Israel
}

(Received 15th February 1972, accepted 8th May 1972)

The infertility of female mice following starvation or insulin administration was attributed to inhibition of adenohypophysial gonadotrophic function due to hypoglycaemia (McClure, 1967). Cows with low blood glucose were less fertile than cows with a rising blood glucose level at about the time of mating (McClure, 1965).

In earlier work, we found that restricting the food consumption of lactating rats to $50 \%$ of that of a group of rats on unrestricted food intake inhibited implantation until the restriction was lifted on the 18th day of pregnancylactation, although there was no decrease in blood glucose (Shapira, 1969). Since the process of implantation is gonadotrophin-dependent (Psychoyos, 1967), it seemed of interest to study the effect of insulin-induced hypoglycaemia unaccompanied by food restriction.

Twenty-four rats mated post partum were allocated to three groups on Day 1 (Day 0-vaginal plug), each rat nursing ten young. The rats were injected subcutaneously with a daily dose of 2 i.u. protamin zinc insulin (Rafa, Israel) per $100 \mathrm{~g}$ body weight since this was found to have the greatest effect in raising feed consumption ( $34 \%$ of the control in a preliminary study). This dose was administered in two equal parts, morning and evening, at a 12-hr interval. Group 1 received insulin from Day 1 to Day 12; Group 2 received insulin from Day 1 to Day 3 in order to study the possible effect of insulin on the fertilized eggs during the preimplantation stage; Group 3 received insulin from Day 1 to Day 3 and again from Day 5 to Day 12. This treatment enabled the blood glucose to recover at the time when the gonadotrophins are expected to affect implantation (Psychoyos, 1967).

On the 12th day of lactation, arterial blood samples were collected with a heparinized syringe from rats under Nembutal anaesthesia. Plasma glucose was determined by the enzymatic method described by Hugget \& Nixon (1957), using Boehringer reagents, $2 \mathrm{hr}, 14 \mathrm{hr}$ and 9 days after the final injection.

Blood glucose recovery within $12 \mathrm{hr}$ after insulin administration was followed by 2 hourly determinations of glucose levels with Dextrostix (Reagent strips produced by Ames, France). The numbers of CL and fetuses were counted and the length of each fetus was measured.

Fourteen hours after administration, blood glucose recovered $(101 \mathrm{mg} / 100$

* Division of Cattle Nutrition and Physiology, The Volcani Center, Agricultural Research Organization, Rehovot, Israel. Contribution No. 2058-E, 1972 series. 
$\mathrm{ml})$ from the low level $(17 \mathrm{mg} / 100 \mathrm{ml})$ found $2 \mathrm{hr}$ after the insulin injection, and almost reached the level found in Group $2(112 \mathrm{mg} / 100 \mathrm{ml}), 9$ days after the final insulin injection. Blood glucose remained below $45 \mathrm{mg} / 100 \mathrm{ml}$ for $8 \mathrm{hr}$ after the injection and did not reach $90 \mathrm{mg} / 100 \mathrm{ml}$ until $12 \mathrm{hr}$ after the injection.

All the females in Groups 1 and 2 were pregnant but only $50 \%$ of those in Group 3 were found to be pregnant (Table 1). The fact that the ratio of the number of $\mathrm{CL} /$ number of fetuses and the mean fetal lengths were about the same

TABLE 1

PREGNANCY RATE AND PERFORMANGE IN LAGTATING RATS TREATED WITH INSULIN

\begin{tabular}{l|c|c|c}
\hline & \multicolumn{3}{|c}{ Days of insulin injections } \\
\cline { 2 - 3 } & $\begin{array}{c}\text { Day 1 to Day 12 } \\
\text { (Group 1) }\end{array}$ & $\begin{array}{c}\text { Day 1 to Day 3 } \\
\text { (Group 2) }\end{array}$ & $\begin{array}{c}\text { Day } 1 \text { to Day } 3 \text { and Day } 5 \text { to } \\
\text { Day 12 (Group 3) }\end{array}$ \\
\hline $\begin{array}{l}\text { No. of pregnant females/ } \\
\text { no. of females injected }\end{array}$ & $8 / 8$ & $8 / 8$ & $4 / 8$ \\
No. of cL/no. of fetuses & $1 \cdot 19$ & 1.22 & $1 \cdot 15$ \\
Mean fetal length (mm) & 6.0 & 6.5 & 6.6 \\
\hline
\end{tabular}

in the three groups shows that insulin treatments did not affect the rate or the time of implantation. The lower number of pregnant females in Group 3 may indicate that the decrease in plasma glucose on Day 5 (renewal of insulin administration) is probably more critical for preserving blastocysts or implantation than a continuous low glucose level (Group 1).

It appears from these data that hypoglycaemia in lactating rats did not inhibit implantation, indicating that the adenohypophysial function in relation to the implantation process was not disturbed.

\section{REFERENCES}

Hugget, A. St.G. \& Nixon, D. A. (1957) Enzymic determination of blood glucose. Biochem. 7. 66, 12P. McClure, T. J. (1965) A nutritional cause of low non-return rate in dairy herds. Aust. vet. J. $41,119$.

McClure, T.J. (1967) Infertility in mice caused by fasting at about the time of mating. III. Parthogenesis. 7. Reprod. Fert. 13, 393.

Psychoyos, A. (1967) The hormonal interplay controlling egg-implantation in the rat. In: Advances in Reproductive Physiology, Vol. II, p. 257. Ed. Anne McLaren. Logos Press, London.

Shapira, N. (1969) Fertility of lactating rats on three nutritional regimes. M.Sc. thesis, Hebrew University of Jerusalem. (Hebrew, with English summary.) 